\title{
Mineral composition of
}

\section{Calligonum aphyllum (Pall.) Guerke.}

[Sluken Rakhmadiyeva, Dina Khalelova, Darya Kushnarevich, Inara Ichshanova]

\begin{abstract}
Calligonum aphyllum (Pall.) Guerke. in the ash residue of a plant, represented by 43 elements in aboveground and root parts by application of spectrometry method with inductevly coupled plasma. Content of heavy metals is within allowable limits.
\end{abstract}

Keywords - Calligonum aphyllum (Pall.) Guerke., mineral composition, MAC (maximum allowable concentration), heavy metals, metnod of spectrometry with inductively-coupled plasma.

\section{Introduction}

Plants of genus Calligonum L. relate to dumetosous of Polygonaceae Juss. family. There are about 80 species of this plant in deserts and plains of Asia and in Middle Asia and about 30 species in Kazakhstan. Calligonum L. - bushes from 0,5 to $4 \mathrm{~m}$ high, many-branched with open head. Calligonum $L$. identify the landscape of many regions in desert zone, they can stand extreme conditions in most of habit areas. Calligonum $L$. grows on sandy and clayed soils, black alkali soils and some types of saltwort. It has long horizontal roots that can reach 12 meters long. They can grow new side (secondary) roots in the base of their stipitates after covering with sand. It makes it a valuable plant for fixing shifting sands (Fig.1). Cleanness of environment is a topical issue of the humanity. Based on the mineral composition of the plant it is possible to identify environmental condition of the region where it grows. In our case it is Aktobe region, which is considered to be industrial zone of the Republic of Kazakhstan.

\section{Materials and methodology}

\section{A. Plant material and reagents}

The plant materials were collected from Aktobe region during flowering stage. The sample was collected in 2013 year. Reference substances: roots, stems, leaves of Calligonum $L$. Physiacl-chemical investigations were carried out using the following equipment: mass spectrometer with inductivelycoupled plasma «Termo Nicolet Avatar-360» (USA), analytical lab mill, analytic balance «Ohaus» (USA), nest of sieves КП - 109/1 (Ukraine), ash muffle SNOL 8.2/1100 (Lithuania).

S. Rakhmadiyeva, D.Khalelova, D. Kushnarevich, I. Ichshanova

L.N. Gumilyov Eurasian National University

Kazakhstan

\section{B. Method of determination of mineral composition}

Method of determination of mineral composition includes:

- preparation of plant material;

- ignition of vegetable stock;

- ash burning;

- examination of ashes residue for mineral composition.

\section{1) Preparation of vegetable stock}

Electrical laboratory mill is used for milling the vegetable stock. Milling is executed in batches right before ignition. The degree of fineness of the stock is defined with the help of screen analysis. Analysis stock sample is milled and screened through the sieve with mesh diameter of $2 \mathrm{~mm}$. Stock loss at this stage of process is $5 \%$ of total amount.

\section{2) Ignition of vegetable stock}

A test portion with a weight of 1-3 g is taken to porcelain crucible pre-heated to fixed mass in order to identify total ash by evenly distributing the substance on the bottom of the crucible. After that the crucible is gradually heated allowing the substance to burn down or volatilize at lower temperature. After the coal is burnt down flame is increased.

\section{3) Ash burning}

Burning in muffle furnace is carried out with low read heat (about $500{ }^{\circ} \mathrm{C}$ ) until constant weight, avoiding melting of ash and its baking with crucible walls. Upon completion of burning the crucible is cooled down in desiccators and weighted. Percent composition of total ash $x$ in absolutely dry stock is defined by the Equation (1):

$$
x=\frac{\mathrm{m}_{\text {ash }} * 100 * 100}{m_{\text {p.c. }} *(100-\omega)}
$$

$\mathrm{m}_{\text {ash }}$ - ash mass, $\mathrm{g}$

$\mathrm{m}_{\text {p.c. }}-$ mass of stock test weight, $\mathrm{g}$

$\omega-$ loss in stock mass during drying, $\%$. 
Proc. of the Intl. Conf. on Advances in Applied science and Environmental Technology - ASET 2015.

Copyright $(\odot$ Institute of Research Engineers and Doctors, USA .All rights reserved.

ISBN: 978-1-63248-040-8 doi: 10.15224/ 978-1-63248-040-8-50

TABLE I. CONTENT OF MINERAL COMPOUNDS IN CALLIGONUM APHYLLUM

\begin{tabular}{|c|c|c|c|c|c|c|c|c|c|c|c|}
\hline № & \multicolumn{2}{|c|}{ Element } & \multirow{2}{*}{$\begin{array}{c}\begin{array}{c}\text { Stems } \\
\mathbf{M g} / \mathbf{k g}\end{array} \\
0,2118\end{array}$} & \multirow{2}{*}{$\begin{array}{c}\begin{array}{c}\text { Leaves } \\
\text { мg/кg }\end{array} \\
0,6669\end{array}$} & \multirow{2}{*}{$\begin{array}{l}\begin{array}{l}\text { Roots } \\
\mathbf{M g} / \mathbf{k g}\end{array} \\
0,271\end{array}$} & \multirow{2}{*}{$\frac{\text { № }}{23}$} & \multicolumn{2}{|c|}{ Element } & \multirow{2}{*}{$\begin{array}{r}\begin{array}{r}\text { Stems } \\
\mathbf{M g} / \mathbf{k g}\end{array} \\
3,12\end{array}$} & \multirow{2}{*}{$\begin{array}{c}\begin{array}{c}\text { Leaves } \\
\text { мg/кg }\end{array} \\
10,6\end{array}$} & \multirow{2}{*}{$\begin{array}{r}\begin{array}{l}\text { Roots } \\
\mathbf{M g} / \mathbf{K g}\end{array} \\
8,832\end{array}$} \\
\hline 1 & Hafnium & Hf & & & & & Niobium & $\mathrm{Nb}$ & & & \\
\hline 2 & Indium & In & $<0,1$ & $<0,1$ & $<0,1$ & 24 & Molybdenum & Mo & 0,17 & 0,515 & 0,2124 \\
\hline 3 & Uranus & $\mathrm{U}$ & $<0,05$ & $<0,05$ & $<0,05$ & 25 & Tin & $\mathrm{Sn}$ & $<0,1$ & $<0,1$ & $<0,1$ \\
\hline 4 & Tantalum & $\mathrm{Ta}$ & $<0,1$ & $<0,1$ & $<0,1$ & 26 & Cerium & $\mathrm{Ce}$ & 1,59 & 3,63 & 5,51 \\
\hline 5 & Gallium & $\mathrm{Ga}$ & $<10$ & $<10$ & $<10$ & 27 & Lithium & $\mathrm{Li}$ & 0,26 & 4 & 0,46 \\
\hline 6 & Scandium & Sc & $<0,1$ & $<0,1$ & $<0,1$ & 28 & Lanthanum & $\mathrm{La}$ & 0,21 & 0,297 & 0,291 \\
\hline 7 & Phosphorus & $\mathrm{P}$ & 872,7 & 1444 & 924 & 29 & Ytterbium & $\mathrm{Yb}$ & 0,019 & 0,022 & 0,024 \\
\hline 8 & Antimony & $\mathrm{Sb}$ & $<0,1$ & $<0,1$ & $<0,1$ & 30 & Yttrium & $\mathrm{Y}$ & 0,55 & 1,07 & 0,84 \\
\hline 9 & Manganese & $\mathrm{Mn}$ & 16,97 & 10,57 & 57,37 & 31 & Silver & $\mathrm{Ag}$ & $<0,1$ & $<0,1$ & $<0,1$ \\
\hline 10 & Titan & $\mathrm{Ti}$ & 25,79 & 21,62 & 26,33 & 32 & Strontium & $\mathrm{Sr}$ & 99,82 & 220,9 & 336,4 \\
\hline 11 & Zirconium & $\mathrm{Zr}$ & 1,93 & 2,33 & 2,53 & 33 & Gold & $\mathrm{Au}$ & $<100$ & $<100$ & $<100$ \\
\hline 12 & Tungsten & W & $<0,1$ & $<0,1$ & $<0,1$ & 34 & Thallium & $\mathrm{Tl}$ & $<0,1$ & $<0,1$ & $<0,1$ \\
\hline 13 & Chrome & $\mathrm{Cr}$ & 4,33 & 3,35 & 5,75 & 35 & Iron & $\mathrm{Fe}$ & 81,73 & 98,05 & 121,5 \\
\hline 14 & Nickel & $\mathrm{Ni}$ & 3,24 & 3,01 & 3,39 & 36 & Platinum & $\mathrm{Pt}$ & $<10$ & $<10$ & $<10$ \\
\hline 15 & Germanium & $\mathrm{Ge}$ & $<0,1$ & $<0,1$ & $<0,1$ & 37 & Thorium & Th & $<0,05$ & $<0,05$ & $<0,05$ \\
\hline 16 & Bismuth & $\mathrm{Bi}$ & $<0,1$ & $<0,1$ & $<0,1$ & 38 & Tellurium & $\mathrm{Te}$ & $<0,1$ & $<0,1$ & $<0,1$ \\
\hline 17 & Barium & $\mathrm{Ba}$ & 10,13 & 14,02 & 29,38 & 39 & Boron & B & 12,52 & 58,96 & 16,78 \\
\hline 18 & Beryllium & $\mathrm{Be}$ & 0,22 & 0,37 & 0,32 & 40 & Aluminum & $\mathrm{Al}$ & 152,07 & 281,34 & 268,08 \\
\hline 19 & Lead & $\mathrm{Pb}$ & $<0,1$ & $<0,1$ & 3,39 & 41 & Cobalt & $\mathrm{Co}$ & 0,561 & 0,519 & 0,5455 \\
\hline 20 & Arsenic & As & $<0,1$ & $<0,1$ & $<0,1$ & 42 & Copper & $\mathrm{Cu}$ & 5,19 & 5,99 & 8,29 \\
\hline 21 & Vanadium & V & 0,99 & 1,73 & 1,49 & 43 & Zinc & $\mathrm{Zn}$ & 8,75 & 9,48 & 10 \\
\hline 22 & Cadmium & $\mathrm{Cd}$ & 0,61 & 0,83 & 1,03 & & & & & & \\
\hline
\end{tabular}

\section{4) Examination of ashes residue for mineral composition}

The evaluation was performed with calibration curves, generated based on the artificial mixtures with preset concentration of microelements. Artificial mixtures were made of spectroscopically pure salts of sodium chloride, calcium carbonate in ratios similar to examined biological objects taking into account coefficients of concentration from oxides of defined elements. There were 43 elements identified in the analyzed samples (Table I).

\section{Results and discussion}

The purpose of the work is to identify mineral composition in different organs of the plant Calligonum aphyllum (Pall.) Guerke.

Species of Calligonum L. - are valuable and useful plants, and all the parts of the plant can be used in complex - cortex, 


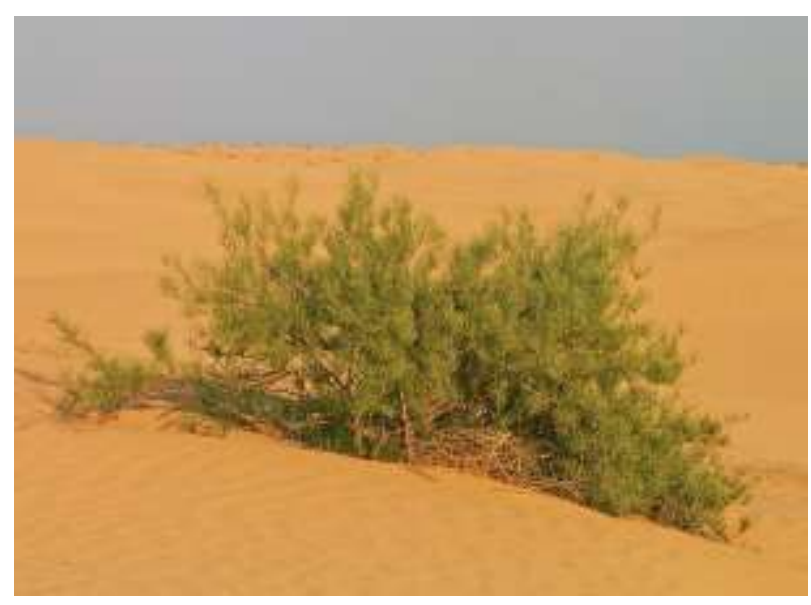

Figure 1. Calligonum aphyllum (Pall.) Guerke.

timber, herbage, blossoms and fruits. Under conditions of natural growth and in culture of different types of Calligonum $L$. sand-fixing properties were studied, as well as productivity of herbage and feeding properties. Economic character of these bushes is significant. Their young branches and fruits that have pleasurable, slightly acid flavor are eaten by sheep and camels. Green branches contain tanning materials. Manmade plantings and natural bushes of Calligonum L. collect snow and as a result of its melting potting soil is desalinated. Plant is used as fuel that provides smokeless fire. Calligonum $L$. is used in traditional medicine for treating abdominal diseases, tooth ache as anti-diabetic agent [1]. It was proven that Calligonum $L$. possesses anti-inflammatory, antiulcerative and cytoprotective properties [2].

Calligonum $L$. grows on the territory of Kazakhstan in: Caspian, Emba, Turgay, Zaisan, Kyzylorda, Aral sea regions; Betpakdala Kizilkum deserts [3].

Object of research is Calligonum aphyllum (Pall.) Guerke., harvested in the neighborhood of Aktobe region in 2013 in the period of blossoming (Fig.2).

Study of mineral composition of plants is an important problem, because due to continuous interdependence of environment and humanity all the components in the plant are eventually contained in human organism. Elements are received by organism from geochemical environment, parent rock materials, soils, natural waters, atmospheric air due to primary organization of biogenic cycles.

TABLE II. DETERMINATION OF IGNITION OF CALLIGONUM APHYLLUM

\begin{tabular}{|c|c|c|c|c|}
\hline № & Stems & Leaves & Blossoms & Roots \\
\hline 1 & 5,42 & 9,96 & 5,43 & 4,45 \\
\hline 2 & 5,18 & 9,97 & 5,17 & 4,43 \\
\hline 3 & 5,39 & 9,05 & 5,37 & 4,5 \\
\hline 4 & 5,78 & 9,82 & 4,07 & 4,46 \\
\hline 5 & 5,77 & 9,57 & 5,77 & 4,45 \\
\hline $\begin{array}{l}\text { Mean } \\
\text { value }\end{array}$ & 5,51 & 9,68 & 5,16 & 4,458 \\
\hline
\end{tabular}

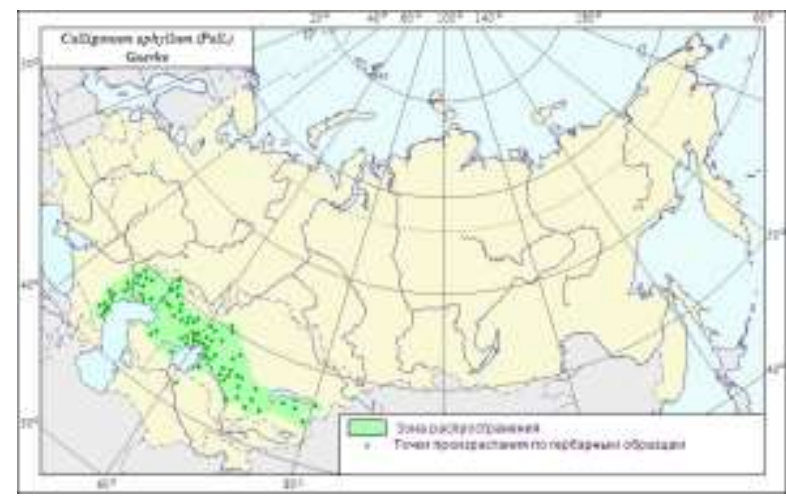

Figure 2. Natural area of Calligonum aphyllum (Pall.) Guerke in Republic of Kazakhstan.

Most of micro and macro-elements have a major impact on life of organisms by connecting with organic matters, synthesized in live cells and often provide their chemical and biologic activity (Table II). They influence fertilization, development, growth, health of an organism, its immunobiological properties, respiratory function of hemoglobin, photosynthesizing function of chlorophyll, fixation of atmospheric nitrogen by microorganisms and other important functions [4].

Mineral components that are important for life in negligibly small quantities become toxic in higher concentrations [5].

There was an interrelation established between soil content of certain chemical elements and production of certain groups of biologically-active substances (BAS) by plants. Plants that produce cardiac glycosides, selectively absorb manganese, molybdenum, chrome; plants producing alkaloids - copper, manganese, cumarins, flavonoids and anthracite-producing copper, vitamins - manganese and copper, polysaccharides manganese, crome [6].

Heavy metals are one of the most widespread contaminants of environment. That is why study of mineral composition of plants has scientific and practical interest. Maximum allowable concentration of heavy metals related to dry stock shall be the following: content of lead shall not exceed 0,5 $\mathrm{mg} / \mathrm{kg}$, copper $-10 \mathrm{mg} / \mathrm{kg}$, zinc $-50 \mathrm{mg} / \mathrm{kg}$.

Quantitative evaluation of contamination of plants with heavy metals not only helps in evaluation of environmental contamination but also their suitability to use as stock for preparation of medical products (Table III).

Based on mineral composition of Calligonum aphyllum (Pall.) Guerke., it is possible to evaluate both content of useful microelements and plant contamination with heavy metals. Elemental composition was identified by application of inductively coupled plasma mass-spectrometry method.

In order to identify mineral composition the stock was preliminary milled and after that burning took place. Method of ash content definition is based on identification of noncombustible residue of non-organic substances that remain after incineration and calcinations of the stock. 
Proc. of the Intl. Conf. on Advances in Applied science and Environmental Technology - ASET 2015.

Copyright $(\odot$ Institute of Research Engineers and Doctors, USA .All rights reserved.

ISBN: 978-1-63248-040-8 doi: 10.15224/ 978-1-63248-040-8-50

TABLE III. CONTENT OF HEAVY METALS IN CALLIGONUM APHYLLUM

\begin{tabular}{|c|c|c|c|c|c|}
\hline \multirow{2}{*}{ N } & \multirow{2}{*}{ Element } & \multicolumn{3}{|c|}{ Content } & MAC \\
\cline { 3 - 6 } & & stems & leaves & roots & Mg/kg \\
\hline 1 & Lead & $<0,1$ & $<0,1$ & 3,39 & 10 \\
\hline 2 & Arsenic & $<0,1$ & $<0,1$ & $<0,1$ & 2 \\
\hline 3 & Vanadium & 0,99 & 1,73 & 1,49 & 15 \\
\hline 4 & Cadmium & 0,61 & 0,83 & 1,03 & 8 \\
\hline 5 & Cobalt & 0,561 & 0,519 & 0,5455 & 23 \\
\hline 6 & Copper & 5,19 & 5,99 & 8,29 & 35 \\
\hline 7 & Zinc & 8,75 & 9,48 & 10 & 10 \\
\hline
\end{tabular}

\section{Conclusion}

Based on the research conducted following conclusions were made:

1) mineral composition of Calligonum aphyllum (Pall.) Guerke. is represented by 43 elements and 16 of them are in negligible quantities;

2) content of heavy elements from $0,1 \mathrm{mg} / \mathrm{kg}$ to 10 stays within maximum allowable concentrations;

3) the plant accumulates heavy metals in required concentrations for growth and thus protects environment.

\section{Acknowledgment}

This publication was made as part of the Sub-project "Development of regulatory technical documentation for the original medical product made of local herbal raw material that possesses hepatoprotective activity", financed as part of the grant program Project "commercialization of technologies" of the component 2: "Development of bonds between science and production" of "Center of commercialization of technologies".

\section{References}

[1] El-Hawary ZM and Kholief TS (1990): Biochemical studies on some hypoglycemic agents (II) effect of Calligonum comosum extract. Arch. Pharm. Res. (13): 113-116

[2] F.A. Badria, M. Ameen, M.R. Akl. Evaluation of cytotoxic compounds from calligonum comosum L. growing in Egypt. Z Naturforsch С. 2007;62(9-10):656-660. (Ger)

[3] С.Я Соколов., О.А Связева., В.А. Кубли. Ареалы деревьев и кустарников СССР. Т.2. Л.: Наука, 1980.- 144 с

[4] А. Г. Подольский. Современные криобиологические технологии переработки растительного сырья / А.Г. Подольский, А.И. Осецкий. - Харьков: НТУ «ХПИ», 2001.

[5] Ю.А. Ершов. Биофизическая химия. Химия биогенных элементов / Ю. А. Ершов и др. - М.: Высш. шк., 2007

[6] Н.И. Гринкевич. Биологическая роль микроэлементов / Н.И. Гринкевич, А.А. Сорокина. - М.: Наука, 1983

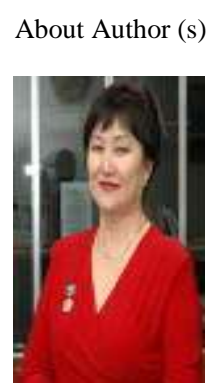

[Sluken B. Rakhmadiyeva graduated from Faculty of Chemistry of the Kazakh

State University in Almaty in 1973, received shis $\mathrm{PhD}$ in Chemistry studies at the Kazakh State University (1974-1977). She carried out postdoctoral studies at the

Kazakh State University (1997-2000).

Doctor of Chemistry Sciences, the Doctoral thesis "The Hydrolysable tannins and related substances purslane plants and their biological activity". She was appointed Lecturer in 1978, and in 2003 he became full Professor of Chemistry at L.N. Gumilyov Eurasian National University

(ENU). Shis research is represented byaround 250 papers and patents covering several topics: bioactive natural products, medicinal chemistry, organic chemistry.

She is now interested on polymeric nanostructures forbiomedical applications.

She has authored three textbooks for students and served the ENU as professor of Chemistry Department and Director of

Research Institute of Bioorganic chemistry, Dean of the Faculty. ]

[Dina Khalelova. I graduated EastKazakhstan State University named after S.Amanzholov as bachelor of natural science in June 2013. Now I study master of Natural science in L.N. Gumilyov Eurasian National University. In 2011 work laboratory assistant for research on «Extraction and analysis of essential oils

from plant material». Also in 2011 I finished Course of «Modern physical and chemical methods of the analysis. High resolution of nuclear magnetic resonance spectroscopy in chemical and biological researches».

Interests: Chemistry of Natural Compounds. 1

[Darya Kushnarevich. I graduated L.N. Gumilyov Eurasian National University as bachelor of natural science in June 2014. I

was studying chemical engineering in

Politechnical University of Gliwice (Poland) as Erasmus student from October 2102 to February 2013. In present time I study master of Natural science in L.N. Gumilyov Eurasian National University and continue to do my bachelor work "Development of new methods for the determination of biologically active substaces in Calligonum aphyllum and extracts of this plant".] 
Proc. of the Intl. Conf. on Advances in Applied science and Environmental Technology - ASET 2015.

Copyright $\odot$ Institute of Research Engineers and Doctors, USA .All rights reserved.

ISBN: 978-1-63248-040-8 doi: 10.15224/ 978-1-63248-040-8-50

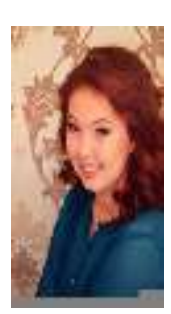

[Inara Ichshanova. I am $4^{\text {th }}$ year bachelor student of chemistry department of Eurasian National University. I have worked in Sanitary epidemiological station as laboratory assistant. My degree work about photochemical research of Calligonum L. Interests: Chemistry of Natural compounds.] 